\title{
PERANCANGAN SISTEM PERAWATAN KOMPONEN V-BELT PADA SISTEM TRANSMISI DENGAN METODE RCM DAN MVSM (STUDI KASUS PT PERKEBUNAN SENTOOL ZIDAM V/BRAWIJAYA JEMBER)
}

\section{DESIGN OF V-BELT COMPONENT TREATMENT IN TRANSMISSION SYSTEM WITH RCM AND MVSM METHOD (CASE STUDY PT PERKEBUNAN SENTOOL ZIDAM V/BRAWIJAYA JEMBER)}

\author{
Gray Miller Damanik ${ }^{1}$, Siswoyo Soekarno ${ }^{2} \bowtie$, Ida Bagus Suryaningrat ${ }^{1}$ \\ ${ }^{1}$ Program Studi Teknologi Industri Pertanian, Fakultas Teknologi Pertanian, Universitas Jember. \\ ${ }^{2}$ Program Studi Teknik Pertanian, Fakultas Teknologi Pertanian, Universitas Jember. \\ ${ }^{\square}$ Komunikasi Penulis, email : siswoyo.s@unej.ac.id \\ DOI:http://dx.doi.org/10.23960/jtep-lv9i4.287-296 \\ Naskah ini diterima pada 16 Juli 2020; revisi pada 10 Desember 2020; \\ disetujui untuk dipublikasikan pada 11 Desember 2020
}

\begin{abstract}
The maintenance system at PT Perkebunan Sentool Zidam V/Brawijaya is the maintenance ofbreakdowns. The syringe process suffers from engine failure and low maintenance inefficiencies. Increasing efficiency can be done by mapping the maintenance value flow (MVSM) and the Reliability Centered Maintenance (RCM) method. Activities using the RCM method formulate the optimal replacement schedule for the V-Belt component, namely 437.4 days ( $V$-Belt delivers power to the drive), 527.386906 days ( $V$-Belt delivers power to the finishing machine), 557.73 days ( $V$-Belt delivery power to the crusher), 557.73 days ( $V$-Belt transmitting power to the six in one engine), and 500.05 days ( $V$-Belt transmitting power to the GT engine). The flow of engine maintenance using the MVSM method has a positive impact on the lag time for engine maintenance to be $36.43 \%$. The results of this study provide several recommendations, namely the implementation of 5S, improvement of standard operating procedures (SOP), training and coaching of workers, and purchasing spare parts before the damage.
\end{abstract}

Keywords: corrective, MVSM, RCM, SOP

\section{ABSTRAK}

Sistem pemeliharaan pada PT Perkebunan Sentool Zidam V/Brawijaya yaitu breakdown maintenance. Proses produksi sering mengalami gangguan akibat kerusakan mesin dan rendahnya efisiensi perawatan. Peningkatan efisiensi perawatan dapat dilakukan dengan pemetaan aliran nilai pemeliharaan (MVSM) dan metode Reilability Centered Maintenance (RCM). Aktivitas pemeliharaan menggunakan metode RCM merumuskan jadwal pergantian optimal pada komponen V-Belt yaitu 437,4 hari (V-Belt penghantar daya ke penggerak), 527,386906 hari (V-Belt penghantar daya ke mesin finishing), 557,73 hari (V-Belt penghantar daya ke mesin penghancur), 557,73 hari (VBelt transmisi penghantar daya ke mesin six in one), dan 500,05 hari (V-Belt transmisi penghantar daya ke mesin GT). Aliran pemeliharaan mesin dengan metode MVSM memberikan dampak positif dengan meningkatnya efisiensi perawatan mesin menjadi 36,43\%. Hasil penelitian ini memberikan beberapa rekomendasi yaitu penerapan 5S, perbaikan standart operational procedure (SOP), pelatihan dan pembinaan tenaga kerja, serta pembelian suku cadang sebelum terjadi kerusakan.

Kata Kunci: korektif, MVSM, RCM, SOP

\section{PENDAHULUAN}

Pemeliharaan (maintenance) merupakan investasi yang secara tidak langsung memberikan profit bagi perusahaan terlebih dalam industri manufaktur. Industri manufaktur memiliki pengertian sebagai cabang industri yang mengaplikasikan mesin, peralatan, tenaga kerja, dan suatu media proses untuk mengubah bahan mentah menjadi produk jadi maupun setengah jadi yang memiliki nilai jual.

Salah satu industri manufaktur yang berada di Kabupaten Jember yaitu PT Perkebunan 
Sentool Zidam V/Brawijaya. Perusahaan ini merupakan unit usaha yang mengolah lateks cair menjadi produk setengah jadi yaitu crepe rubber. Bahan baku produksi crepe rubber beresiko tinggi mengalami penurunan mutu apabila tidak segera diolah, oleh karena itu sangatlah penting bagi perusahaan untuk memastikan setiap aset mesin dapat beroperasi sesuai dengan fungsinya untuk menjaga kelancaran penyerapan bahan baku. Pada pengaplikasiannya perusahaan ini sering mengalami gangguan produksi akibat mesin yang rusak (breakdown) dan efisiensi perawatan yang rendah. Selama periode Februari 2016 hingga Februari 2020 terdapat sebanyak 58 kasus kerusakan mesin dan ditangani menggunakan sistem breakdown. Aktivitas perawatan tidak sepenuhnya memberikan nilai tambah, akan tetapi juga sebaliknya, bahkan apabila tidak dilakukan manajemen yang baik akan mengakibatkan perbaikan berulang-ulang, pemborosan waktu dan aktivitas, dengan demikian perusahaan perlu melakukan pengembangan maintenance (pemeliharaan) yang terstruktur. RCM dan MVSM merupakan metode yang sering digunakan untuk pengembangan maintenance. Metode ini sangat efektif digunakan untuk menjamin setiap aset beroperasi sesuai dengan fungsinya dan mengurangi pemborosan aktivitas.

\section{BAHAN DAN METODE}

Bahan yang digunakan pada penelitian ini terdiri dari lembar kerja meliputi pertanyaan wawancara, dan literatur (buku dan jurnal). Alat yang digunakan berupa perangkat komputer, kamera, alat tulis, microsoft office word, microsoft office excel, visio, dan aplikasi easyfit 5.6. Metode yang digunakan pada penelitian ini terdiri dari 2 yaitu RCM dan MVSM. Tahapan penelitian dapat dilihat pada diagram alir berikut ini (Gambar 1).

Output dari pengembangan maintenance menggunakan metode RCM yaitu interval pergantian komponen optimal dan downtime yang rendah. Langkah-langkah penggunaan metode ini yaitu:

1. Pemilihan sistem dan pengumpulan informasi,
2. Pendefinisian batasan sistem,

3. Deskripsi sistem dan blok diagram,

4. Fungsi sistem dan kegagalan fungsi,

5. Failure mode and effect analysis (FMEA) yaitu dengan menghitung nilai RPN dengan menggunakan persamaan:

$$
\mathrm{RPN}=\mathrm{S} \times \mathrm{O} \times \mathrm{D}
$$

dimana RPN adalah Risk Priority Number, $\mathrm{S}$ adalah nilai saverity (tingkat keparahan), 0 adalah nilai occurence (tingkat kejadian), dan D adalah Nilai detection (deteksi).

6. Penentuan distribusi data menggunakan aplikasi easyfit 5.5. Pada tahap ini dilakukan validasi jenis pola distribusi menggunakan pengujian kolmogorov smirnov,

7. Perhitungan MTTF dan MTTR berdasarkan pola distribusi data menggunakan persamaan berikut:

$$
\begin{aligned}
& \text { Normal }=\mu \\
& \text { Lognormal }=\mu \frac{\sigma^{2}}{2} \\
& \text { Eksponensial }=\frac{1}{\lambda} \\
& \text { Weibull }=\alpha \Gamma\left(1+\frac{1}{\beta}\right)
\end{aligned}
$$

8. Perhitungan interval perawatan $\mathrm{rcm}$ decision worksheet. Persamaan menghitung interval perawatan optimal yaitu:

$$
T_{i}=\frac{\text { Rata-rata jam kerja per bulan }}{n}
$$

Sebelum melakukan perhitungan interval perawatan komponen optimum perlu diketahui frekuensi pemeriksaan optimum dan waktu rata-rata jam kerja per bulan. Frekuensi pemeriksaaan optimum dihitung menggunakan persamaan berikut:

$$
\mathrm{n}=\sqrt{\frac{k, i}{\mu}}
$$

dimana k adalah rata-rata kerusakan, i adalah waktu rata-rata melakukan pemeriksaan, adalah waktu melakukan perbaikan.

Efektivitas perawatan dapat dilihat dari downtime, oleh karena itu setelah rancangan waktu perawatan optimum dapat dihitung downtime sebagai perbandingan dengan downtime sebelum usulan. Perhitungan dilakukan menggunakan Persamaan 8.

$$
\mathrm{D}=\frac{K}{\mu \cdot n}+\frac{1}{i}
$$

Output dari pengembangan maintenance menggunakan metode MVSM yaitu pemetaan aliran proses perawatan mesin, eliminasi 


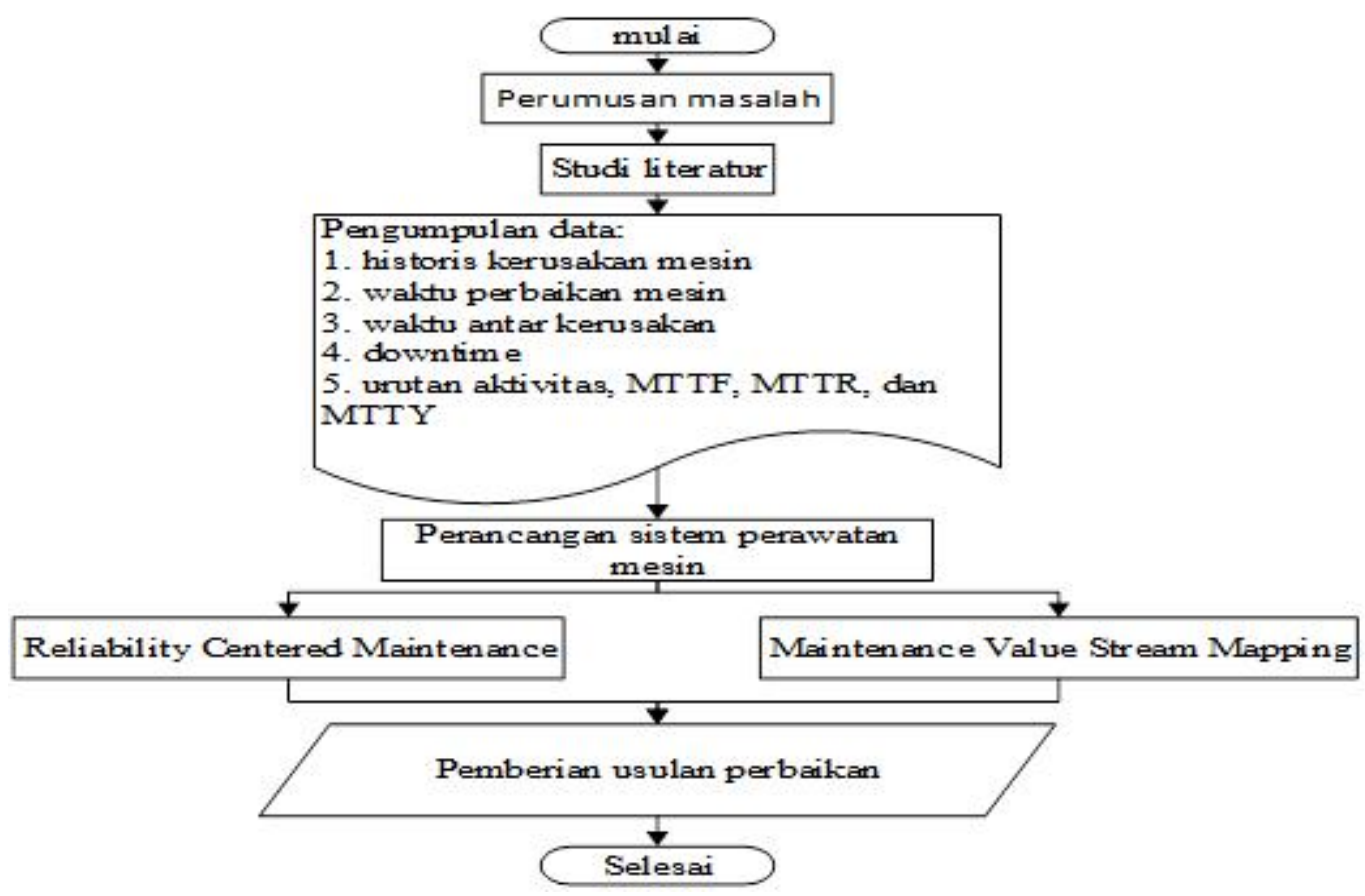

Gambar 1. Tahapan Penelitian

aktivitas yang tidak memberikan nilai tambah dan rekomendasi perbaikan. Langkahlangkah penggunaan metode ini yaitu:

1. Pembuatan kerangka current state map,

2. Pembuatan kerangka future state map,

3. Perhitungan efisiensi aktivitas perawatan mesin dengan menggunakan Persamaan 9.

$$
\mathrm{ME}=\mathrm{VA} / \mathrm{NVA} \times 100 \%
$$

dimana ME adalah maintenance efficiency, VA adalah waktu aktivitas yang memberikan nilai tambah, NVA adalah waktu aktivitas yang tidak memberikan nilai tambah diagram sebab akibat, dan rekomendasi perbaikan.

4. Diagram sebab akibat, dan

5. Rekomendasi perbaikan.

\section{HASIL DAN PEMBAHASAN}

\subsection{RCM}

\subsubsection{Pemilihan Sistem}

Terdapat 3 sistem di PT Perkebunan Sentool Zidam V/Brawiaya diantaranya;1)sistem transmisi;2)sistem gilingan;3)sistem penggerak. Pada Gambar 2 dapat dilihat bahwa sistem sering mengalami kerusakan yaitu sistem transmisi dengan total sebanyak 36 kali kerusakan selama 4 tahun terakhir, sehingga penelitian ini akan difokuskan pada sistem transmisi.

\subsubsection{Batasan Sistem}

Berdasarkan pemilihan sistem tersebut dibuat batasan sistem untuk membedakan antara sistem yang satu dengan yang lainnya. Pada sistem tranmisi terdapat 3 komponen yaitu $V$-Belt, laker, dan baut bodi.

\subsubsection{Deskripsi Sistem dan Blok Fungsi}

Adapun deskripsi sistem transmisi sebagai berikut: 1) transfer daya gerak/putaran dari sistem penggerak. Energi gerak yang timbul akibat aktivitas sistem penggerak yaitu berupa turbin dan generator akan ditransfer melalui sistem transmisi meliputi pipa transmisi, laker/ bearing, roda dan $V$-Belt dan 2) pendistribusian gerak/putaran, dilakukan dengan menyambung transmisi penggerak ke transmisi gilingan menggunakan pipa yang dilengkapi laker. Visualisasi struktur fungsi dengan jelas digambarkan pada blok fungsi yang dapat dilihat pada Gambar 3.

\subsubsection{Fungsi Sistem dan Kegagalan Fungsi}

Pendeskripsian fungsi dan kegagalan sistem dilakukan dengan cara pemberian kode dengan kode huruf diikuti 1 angka untuk melambangkan nama unit proses dari sistem transmisi, huruf diikuti 2 angka melambangkan fungsi komponen utama sistem tersebut, dan huruf diikuti 3 angka 
melambangkan kegagalan fungsi unit tersebut. Hasil rekapitulasi menunjukkan kode A1 merupakan kode fungsi $\mathrm{V}$-Belt penghantar daya dari stasiun penggerak, A2 fungsi V-Belt penghantar ke mesin finishing, A3 fungsi V-Belt penghantar ke mesin penghancur, A4 fungsi VBelt penghantar ke mesin six in one, A5 fungsi $V$ Belt penghantar ke mesin GT.

Kegagalan fungsi dilambangkan kode 3 digit, yaitu A.1.1 menggambarkan kegagalan fungsi komponen V-Belt penghantar daya dari stasiun penggerak, A.1.2 menggambarkan kegagalan fungsi komponen V-Belt penghantar daya ke mesin finishing, A.1.3 menggambarkan kegagalan fungsi komponen V-Belt penghantar daya ke mesin penghancur, A.1.4 menggambarkan kegagalan fungsi komponen V-Belt penghantar daya ke mesin six in one, dan A.1.5 menggambarkan kegagalan fungsi komponen $\mathrm{V}$ Belt penghantar daya ke mesin GT.

\subsubsection{Failure Mode and Effect Analysis (FMEA)}

Penilaian RPN dilakukan melalui 3 aspek yaitu tingkat keparahan efek (saverity), kemungkinan terjadinya kegagalan yang berhubungan dengan efek (occurence), serta kemampuan mendeteksi kegagalan sebelum terjadi (detection). Penilaian dilakukan menggunakan skala 1 sampai 10 . Berdasarkan analisis dan perhitungan didapatkan nilai RPN pada masing masing komponen yang ditunjukkan pada Tabel 1 .

\subsubsection{Logic Tree Analysis (LTA)}

Berdasarkan struktur logic tree yang telah dibuat, diperoleh rekapitulasi (Tabel 2) yang menunjukkan bahwa kegagalan pada mesin produksi tidak menyebabkan efek keselamatan pada pekerja, akan tetapi menyebabkan sebagian atau seluruh mesin tidak dapat beroperasi. Mode kegagalan termasuk kategori $B$, artinya kerusakan mengakibatkan mesin tidak dapat beroperasi sebagian atau total.

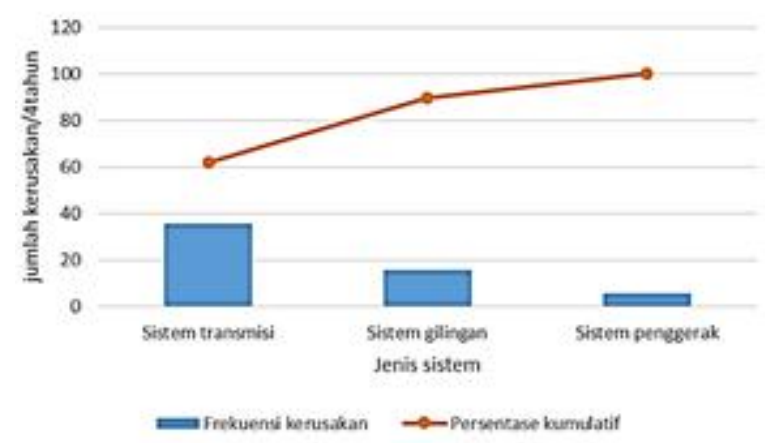

Gambar 2. Data Jumlah Kerusakan Periode Februari 2016-Februari 2020

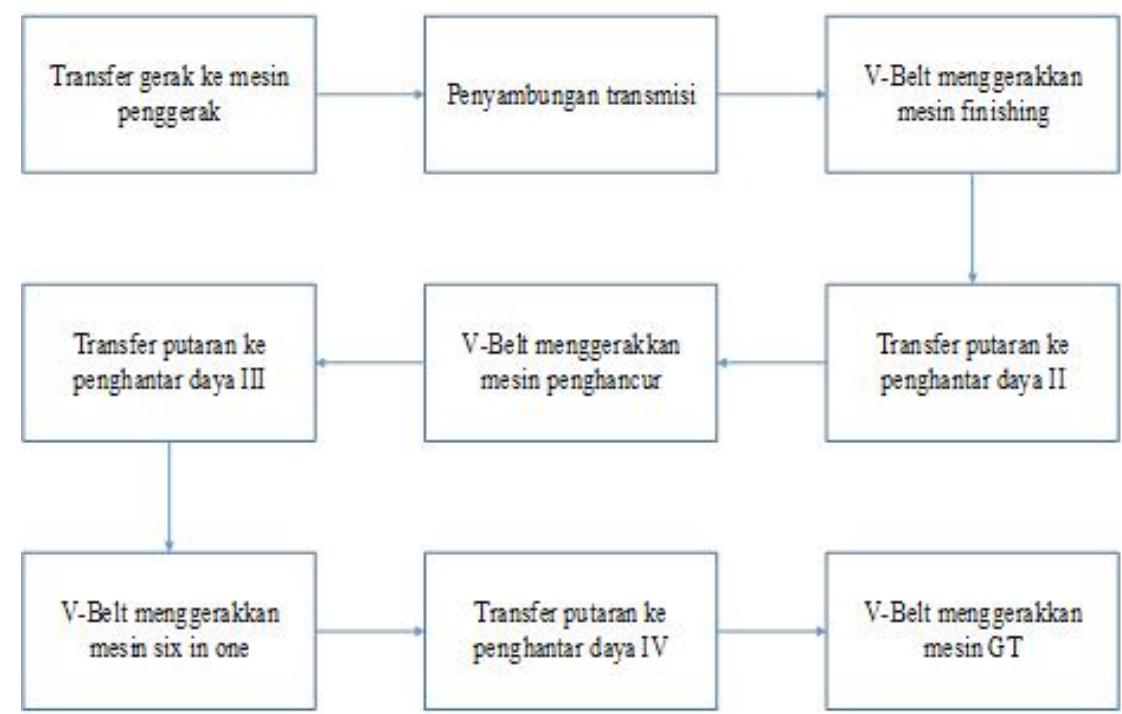

Gambar 3. Blok Diagram Sistem Transmisi PT Perkebunan Sentool Zidam/Brawijaya 


\subsubsection{Pola Distribusi Data}

Hasil pengujian pola distribusi waktu antar kerusakan dan waktu antar perbaikan menggunakan sofware easyfit 5.6 profesional diperoleh parameter dan distribusi data dari masing-masing komponen mesin. Parameterparameter yang dihasilkan oleh aplikasi ini digunakan untuk menghitung MTTF, MTTR, dan total minimum downtime. Pendekatan reliability menggunakan 4 pola distribusi diantaranya distribusi normal, lognormal, eksponensial, dan Weibull. Penentuan pola distribusi didasari oleh nilai statistik yang paling tinggi pada software easyfit 5.6. Validasi data diuji menggunakan uji kolmogorov smirnov menggunakan aplikasi yang sama. Berdasarkan pengamatan diperoleh dua jenis distribusi data yang diinput yaitu eksponensial dan Weibull. Adapun rekapitulasi hasil pengujian pola distribusi dapat dilihat pada Tabel 3 dan Tabel 4. Parameter pola distribusi data berbeda-beda tergantung jenis distrbusi data. Parameter distribusi eksponensial yaitu $\lambda$ sedangkan weibul $\theta$ dan $\beta$. Hasil pengujian menunjukkan distribusi data waktu antar kerusakan A1, A2, A3, dan A4 terdistribusi eksponensial sedangkan A5 weibull. Hasil pengujian distribusi data waktu antar perbaikan menunjukkan seluruh data terdistribusi eksponensial.

Berdasarkan hasil pola distribusi, dapat dilakukan waktu rata-rata kegagalan (MTTF) dan waktu rata-rata perbaikan (MTTR). Perhitungan MTTF dan MTTF dilakukan berdasarkan masing-masing pola distribusi. Perhitungan MTTF dan MTTR dilakukan menggunakan 2 jenis dsitribusi berdasarkan pengujian yang dilakukan menggunakan software easyfit 5.6. Hasil perhitungan MTTF dan MTTR dapat dilihat pada Tabel 5.

Tabel 1. Nilai RPN

\begin{tabular}{cccccl}
\hline Nama Komponen & S & O & D & RPN & Rank \\
\hline A1 & 8 & 10 & 8 & 640 & 1 \\
A2 & 7 & 7 & 8 & 392 & 3 \\
A3 & 7 & 7 & 8 & 392 & 4 \\
A4 & 7 & 7 & 8 & 392 & 5 \\
A5 & 7 & 8 & 8 & 448 & 2 \\
\hline
\end{tabular}

Tabel 2. Rekapitulasi LTA

\begin{tabular}{ccccccc}
\hline No & Komponen & Failure Mode & Evident & Safety & Outage & Category \\
\hline 1 & $A 1$ & V-Belt putus atau melar & $\mathrm{Y}$ & $\mathrm{T}$ & $\mathrm{Y}$ & $\mathrm{B}$ \\
2 & $A 2$ & V-Belt putus atau melar & $\mathrm{Y}$ & $\mathrm{T}$ & $\mathrm{Y}$ & $\mathrm{B}$ \\
3 & $A 3$ & V-Belt putus atau melar & $\mathrm{Y}$ & $\mathrm{T}$ & $\mathrm{Y}$ & $\mathrm{B}$ \\
4 & $A 4$ & V-Belt putus atau melar & $\mathrm{Y}$ & $\mathrm{T}$ & $\mathrm{Y}$ & $\mathrm{B}$ \\
5 & $A 5$ & V-Belt putus atau melar & $\mathrm{Y}$ & $\mathrm{T}$ & $\mathrm{Y}$ & $\mathrm{B}$ \\
\hline
\end{tabular}

Tabel 3. Pola Distribusi Data Waktu Antar Kerusakan

\begin{tabular}{ccc}
\hline Komponen & Pola distribusi & Parameter \\
\hline A1 & Eksponensial & $\lambda=0,007$ \\
A2 & Eksponensial & $\lambda=0,0039$ \\
A3 & Eksponensial & $\lambda=0,0042$ \\
A4 & Eksponensial & $\lambda=0,0038$ \\
A5 & Weibull & $\theta=179,6 \beta=0,83$ \\
\hline
\end{tabular}

Tabel 4. Hasil Pengujian Distribusi Data Waktu Antar Perbaikan

\begin{tabular}{ccc}
\hline Komponen & Pola distribusi & Parameter \\
\hline A1 & Eksponensial & $\lambda=0,019$ \\
A2 & Eksponensial & $\lambda=0,02$ \\
A3 & Eksponensial & $\lambda=0,019$ \\
A4 & Eksponensial & $\lambda=0,019$ \\
A5 & Eksponensial & $\lambda=0,018$ \\
\hline
\end{tabular}


Tabel 5. Hasil Perhitungan MTTF dan MTTR

\begin{tabular}{ccc}
\hline Nama Komponen & MTTF (hari) & MTTR (menit) \\
\hline A1 & 143,06 & 51,44 \\
A2 & 251,89 & 50,99 \\
A3 & 235,85 & 53,1 \\
A4 & 265,96 & 53,1 \\
A5 & 199,13 & 57,01 \\
\hline
\end{tabular}

Tabel 6. Interval Waktu Penggantian Komponen Mesin

\begin{tabular}{ccc}
\hline No & Nama Komponen & Interval Waktu Penggantian (hari) \\
\hline 1 & A1 & 437,40 \\
2 & A2 & 527,39 \\
3 & A3 & 557,73 \\
4 & A4 & 557,73 \\
5 & A5 & 500,05 \\
\hline
\end{tabular}

\subsubsection{Interval Penggantian Komponen}

Penentuan interval perawatan perlu dilakukan untuk dapat mengetahui waktu perbaikan atau mempersiapkan penggantian komponen sehingga produksi tetap berjalan optimal. Jumlah hari produksi pada PT Perkebunan Sentool yaitu sebanyak 30 hari dengan jam kerja per hari yaitu 6 jam. Perhitungan waktu pergantian komponen optimal dapat dilakukan apabila frekuensi pemeriksaan optimal diketahui. Berdasarkan perhitungan yang dilakukan diperoleh frekuensi pemeriksaan optimal yaitu 0,41 jam, 0,34 jam, 0,32 jam, 0,32 jam, dan 0,36 jam. Berdasarkan perhitungan yang telah dilakukan diperoleh interval penggantian komponen yang ditunjukkan pada Tabel 6 . Hasil perhitungan menunjukkan bahwa waktu perawatan optimum komponen V-Belt pada sistem transmisi yaitu mulai dari 437, 4 hari hingga 557,73 hari. Masing-masing V-Belt memiliki intensitas kerusakan yang berbeda-beda dikarenakan tekanan dan beban kerja yang berbeda, sehingga waktu perawatan optimum bervariasi. Setelah didapatkan interval penggantian komponen optimal, maka dapat dihitung downtime perawatan usulan. Berdasarkan perhitungan yang telah dilakukan diperoleh downtime yaitu sebesar 0,006 jam, 0,0057 jam, 0,0066 jam, 0,0066 jam, dan 0,0069 jam tergantung komponen $\mathrm{V}$-Beltnya.

\subsubsection{RCM Decision Worksheet}

Berdasarkan analisis RCM Worksheet dapat diperoleh beberapa tindakan perawatan yang diusulkan untuk meningkatkan keandalan [2]. Adapun tindakan yang dapat diambil antara lain:

1. V-Belt penghantar daya mesin ke penggerak Scheduled on condition task dengan interval penggantian komponen yaitu 437,40 hari sebagai acuan.

2. V-Belt penghantar daya ke mesin finishing Scheduled on condition task dengan interval penggantian komponen yaitu 527,39 hari sebagai acuan.

3. V-Belt penghantar daya ke mesin penghancur Scheduled on condition task dengan interval penggantian komponen yaitu 557,73 hari sebagai acuan.

4. V-Belt penghantar daya ke mesin six in one Scheduled on condition task dengan interval penggantian komponen yaitu 557,73 hari sebagai acuan.

5.V-Belt penghantar daya ke mesin GT Scheduled on condition task dengan interval penggantian komponen yaitu 500,05 hari sebagai acuan.

\subsection{MVSM (Maintenance Value Stream Mapping)}

Berdasarkan identifikasi didapatkan bahwa sistem transmisi memiliki downtime paling tinggi (dapat dilihat pada Gambar 4). Terdapat 3 komponen pada sistem transmisi yaitu V-Belt, baut bodi, dan laker. Total jumlah kerusakan komponen V-belt pada periode Februari 2016Februari 2020 yaitu sebanyak 34 kerusakan dan merupakan yang paling tinggi, sehingga penelitian ini berfokus pada komponen V-Belt. 


\subsubsection{Current State Map}

Berdasarkan identifikasi melalui wawancara didapatkan gambaran kondisi perawatan aktual, kategori MMLT. Setelah pembuatan kerangka current state map (Gambar 5) diperoleh rekapitulasi aktivitas perawatan dan durasi waktu yang ditunjukkan pada Tabel 7. Pada tabel tersebut dapat dilihat jumlah waktu yang memberikan nilai tambah dan waktu yang tidak memberikan nilai tambah yang akan digunakan pada perhitungan dan evaluasi efisiensi perawatan aktivitas perawatan mesin.

Berdasarkan pengamatan dan perhitungan Mean Minute Lead Time (MMLT), Mean Time To Repair (MTTR), Mean Time To Operation (MTTO), dan Mean Time To Yield (MTTY) dapat dihitung efisiensi perawatan. Dari hasil perhitungan diperoleh bahwa efisiensi perawatan aktual komponen $V$-Belt yaitu sebesar 9,25\%, kondisi ini akan meningkat dengan merancang future state map yaitu dengan mengurangi aktivitas tidak memberikan nilai tambah.

\subsubsection{Future State Map}

Future state map (Gambar 6) merupakan perbaikan dari current state map yaitu dengan mengurangi aktivitas tidak memberikan nilai tambah dengan tujuan untuk meningkatkan efisiensi perawatan dimasa yang akan datang. Berdasarkan identifikasi dan pembuatan kerangka future state map diperoleh rekapitulasi aktivitas perawatan aktual, kategori MMLT, dan durasi waktu yang ditunjukkan pada Tabel 8.

Berdasarkan perhitungan diatas juga dapat dihitung efisiensi perawatan yaitu sebesar $36,43 \%$. Hasil tersebut meningkat sebesar $27,18 \%$ dari perawatan aktual atau sebelumnya.

\subsubsection{Penyebab Perawatan Kurang Efisien} Observasi di lapangan dan wawancara dengan karyawan ditemukan beberapa penyebab tidak efisiennya aktivitas perawatan pada PT Perkebunan Sentool Zidam V/Brawijaya di antaranya kondisi mesin, kondisi lingkungan, material, metode perawatan yang digunakan, dan sumber daya manusia. Analisa ini dilakukan menggunakan diagram sebab akibat atau fish bone yang terlihat pada Gambar 7.

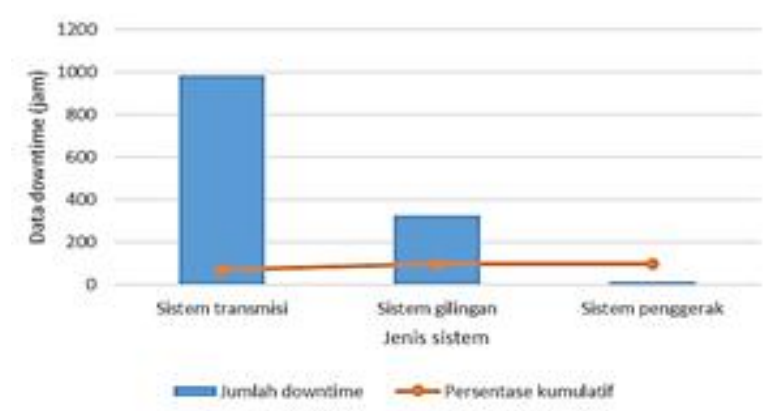

Gambar 4. Data Downtime Sistem Mesin di PT Perkebunan Sentool Zidam V/Brawijaya Periode Februari 2016-Februari 2020

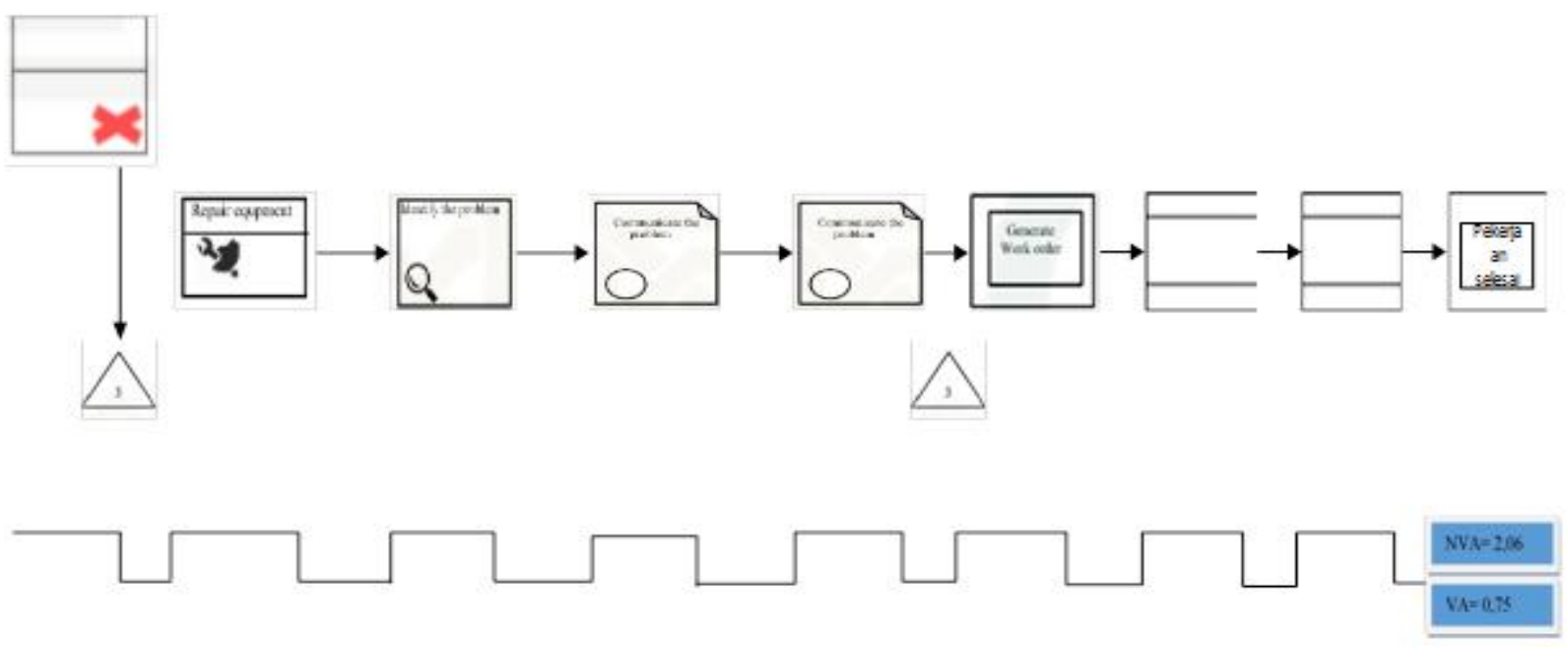

Gambar 5. Kerangka Current State Map 
Tabel 7. Rekapitulasi Current State Map

\begin{tabular}{|c|c|c|c|c|}
\hline No & Aktivitas Perawatan & $\begin{array}{c}\text { Durasi } \\
\text { (jam) }\end{array}$ & $\begin{array}{l}\text { Kategori } \\
\text { MMLT }\end{array}$ & $\begin{array}{l}\text { NVA/V } \\
\text { A }\end{array}$ \\
\hline 1 & Kerusakan mesin & - & - & 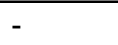 \\
\hline 2 & $\begin{array}{l}\text { Delay akibat operator tidak berada ditempat/sedang melakukan } \\
\text { pekerjaan lain }\end{array}$ & 0,05 & MTTO & NVA \\
\hline 3 & Pemeriksaan kerusakan & 0,25 & MTTO & NVA \\
\hline 4 & Laporan ke kepala bagian produksi & 0,166 & MTTO & NVA \\
\hline 5 & Pengajuan penggantian $V$-Belt/perbaikan ke bagian pengadaan & 0,083 & MTTO & NVA \\
\hline 6 & Delay menunggu persetujuan pimpinan & 6 & МTTO & NVA \\
\hline 7 & Pembelian spare part & 1,5 & MTTO & NVA \\
\hline 8 & Persiapan untuk perbaikan & 0,03 & MTTO & NVA \\
\hline 9 & Perbaikan V-Belt & 0,75 & MTTR & VA \\
\hline 10 & Menjalankan mesin sekaligus mengecek kenormalan & 0,03 & MTTY & NVA \\
\hline \multirow[t]{5}{*}{11} & Perawatan mesin selesai & - & - & - \\
\hline & Jumlah MMLT & 8,859 & & \\
\hline & MTTO & 8,0823 & & \\
\hline & MTTR & 0,75 & & \\
\hline & MTTY & 0,03 & & \\
\hline
\end{tabular}

Tabel 8. Rekapitulasi Future State Map

\begin{tabular}{|c|c|c|c|c|}
\hline No & Aktivitas perawatan & $\begin{array}{l}\text { Durasi } \\
\text { (jam) }\end{array}$ & $\begin{array}{c}\text { Kategori } \\
\text { MMLT }\end{array}$ & NVA/VA \\
\hline 1 & Kerusakan mesin & - & - & - \\
\hline 2 & Pemeriksaan kerusakan oleh mekanik & 0,25 & MTTO & NVA \\
\hline 3 & Laporan ke kepala bagian produksi & 0,17 & MTTO & NVA \\
\hline 4 & Pengajuan perbaikan ke bagian pengadaan & 0,08 & MTTO & NVA \\
\hline 5 & Pembelian spare part & 1,5 & MTTO & NVA \\
\hline 6 & Persiapan untuk perbaikan & 0,03 & MTTO & NVA \\
\hline 7 & Perbaikan $V$-Belt & 0,75 & MTTR & VA \\
\hline 8 & $\begin{array}{l}\text { Menjalankan mesin sekaligus melakukan pengecekan } \\
\text { apakah mesin sudah berjalan normal atau tidak }\end{array}$ & 0,03 & MTTY & NVA \\
\hline \multirow[t]{5}{*}{9} & Perawatan mesin selesai & - & - & - \\
\hline & Jumlah MMLT & 2,81 & & \\
\hline & MTTO & 2,029 & & \\
\hline & MTTR & 0,75 & & \\
\hline & MTTY & 0,03 & & \\
\hline
\end{tabular}
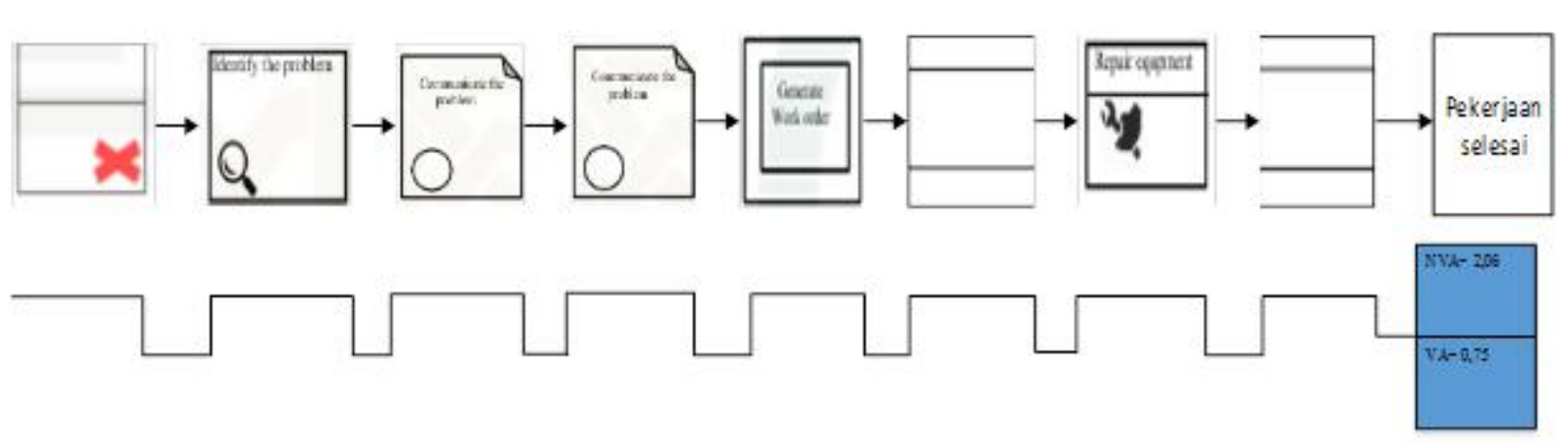

Gambar 6. Kerangka Future State Map

Berdasarkan uraian pemetaan tersebut menunjukkan bahwa terjadi peningkatan jumlah waktu aktivitas yang memberikan nilai tambah dan penurunan waktu aktivitas yang tidak memberikan nilai tambah. Pemetaan future state map didasarkan pada analisis kondisi perawatan aktual, dimana aktivitas menunggu acc pimpinan menjadi penyumbang pemborosan waktu perawatan mesin, dengan demikian dirancang aktivitas perawatan mesin dengan 


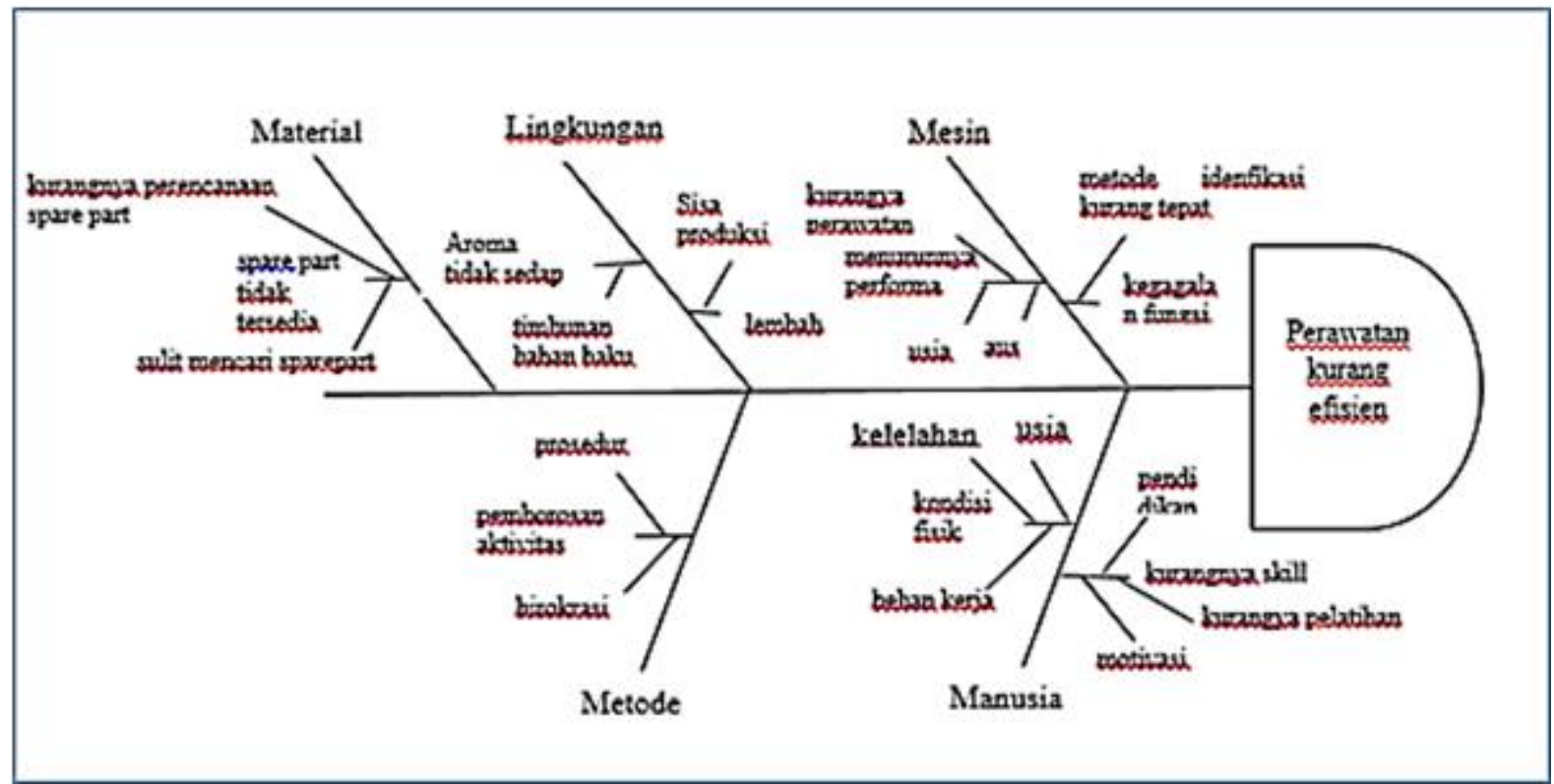

Gambar 7. Diagram Sebab Akibat Aktivitas Perawatan Mesin Kurang Efisien

mengeliminasi dan memperpendek birokrasi acc pimpinan perusahaan. Tindakan tersebut memungkinkan untuk dilakukan dengan menerapkan standard operational procedure (SOP) baru dan koordinasi yang baik antara pimpinan dan bawahan untuk memastikan setiap item mesin dapat beroperasi sesuai dengan fungsinya.

\subsubsection{Rekomendasi perbaikan}

Rekomendasi diberikan dengan tujuan untuk meminimasi aktivitas-aktivitas yang tidak memberikan nilai tambah dan membuat aktivitas perawatan seefisien mungkin. Adapun rekomendasi yang diberikan di antaranya:

1. Penerapan metode $5 S$ pada lingkungan kerja. Adapun 5S terdiri dari Sort (Seiri), Straighten (Seiton), Shine (Seiso), Standarize (Seiketsu), Sustain (Shitsuke). Penerapan metode ini membutuhkan kedisiplinan karyawan untuk menjaga dan mengkondisikan lingkungan kerja supaya tetap nyaman.

2. Pembelian spare part dilakukan di awal sebelum kerusakan.

3. Pembuatan SOP perbaikan komponen mesin. Pembuatan SOP akan menjadikan karyawan lebih terstruktur dalam melakukan perbaikan mesin guna meminimalisir waktu pemborosan.

4. Pembinaan dan pelatihan operator/mekanik. Pembinaan ini perlu dilakukan guna menyiapkan tenaga kerja untuk terampil melakukan perbaikan mesin sehingga perusahaan tidak harus menyewa montir dari luar.

\section{KESIMPULAN}

Efisiensi perawatan aktual komponen V-Belt yaitu sebesar 9,25\% sedangkan efisiensi perawatan usulan sebesar $36,43 \%$. Hasil tersebut meningkat sebesar $27,18 \%$ dari perawatan aktual. Apabila dibandingkan perawatan aktual terjadi peningkatan aktivitas yang memberikan nilai tambah sebesar 18,3\% dan penurunan aktivitas yang tidak memberikan nilai tambah sebesar 19,37\%. Perancangan perawatan menggunakan metode RCM di PT Perkebunan Sentool Zidam V/Brawijaya menghasilkan downtime yang relatif kecil yaitu V-Belt penghantar daya ke sistem penggerak 0,0066 , V-Belt penghantar daya ke mesin finishing 0,0057, V-Belt penghantar daya ke sistem penghancur 0,0066 , V-Belt penghantar daya ke mesin six in one 0,0066 , dan V-Belt penghantar daya ke mesin GT 0,0069. Interval perawatan optimal komponen $\mathrm{V}$-Belt penghantar daya ke sistem penggerak yaitu 437,40 hari, VBelt pensghantar daya ke mesin finishing 527,39 hari, V-Belt penghantar daya ke sistem penghancur 557,73 hari, V-Belt penghantar daya ke mesin six in one 557,73 hari, dan V-Belt penghantar daya ke mesin GT 500,05 hari. 


\section{DAFTAR PUSTAKA}

Al-Ghamdi, A.S., Duffuaa, S.O., Raouf, A. 2005. Reliability Centered Maintenance Concepts and Applications: A Case Study. International Journal of Industrial Engineering - Theory, Applications And Practice 7: 123-132.

Assauri, S. 2008. Manajemen Produksi dan Operasi. Jakarta: Lembaga Penerbit Fakultas Ekonomi Universitas Indonesia.

Faizal, M. 2017. Implementasi Reliability Centered Maintenance Pada Proses Peleburan Polimer Keramik Di PT. Ferro Indonesia . Disertasi. Surabaya: Institut Teknologi Sepuluh Nopember.

Matondang, N., P. Oktalisa., dan A. Ishak. 2013. Perancangan Sistem Perawatan Mesin Dengan Pendekatan Reliability Engineering dan Maintenance Value Stream Mapping (MVSM) Pada PT XXX. http:// jurnal.usu.ac.id/index.php/jti/article/ view [diakses 02 April 2020].

Nainggolan, E. 2017. Penerapan Metode Reliability Cenetered Maintenance Menggunakan Software SPSS Pada Sistem Pendingin Generator Mitsubishi Kapasitas
62500 Kva. Skripsi. Medan: Universitas Sumatera Utara.

Sawhney, R., dan S. Kannan. 2009. Developing a value stream map to evaluate breakdown maintenance operations. International Journal Industrial and System Enggineering 4(3).

Sehrawat, M. S., dan J. S. Narang. 2001. Production Manajemen, 3 rd Edition. Delhi: Dhonpat Rai \& Co.

Sudiyono, B., dan N. Qomariyah. 2018. Pengaruh Motivasi, Kompensasi, dan Komitmen terhadap Kinerja Karyawan (Studi Kasus pada Karyawan PT. Tirta Investama DC Rungkut). International Journal of Social Science and Business 2(3): 150-15.

Syaief, A. N., dan Y. Irawan. 2012. Perancangan Maintenance Value Stream Mapping (MVSM) pada Ketel Yoshimine I Stasiun Ketel Guna Meningkatkan Kualitas Pemeliharaan di PT PG X. Tesis. Program Magister Teknik Mesin, Program Pascasarjana, Fakultas Teknik, UB, Malang.

Winandi, A. 2012. Reliability Centered Maintenance Pada Pompa. Skripsi. Depok: Universitas Indonesia. 